\title{
The Extract Obtained from Two Radish Cultivars (Raphanus sativus L. and Raphanus sativus L. var. radikula) Using Liquid Nitrogen Is Germination of Sterile Oats (Avena sterilis Subsp. sterilis) and Allelopathic Effect on Seedling Growth
}

\author{
Duygu Sisek ${ }^{1}$, Suleyman Turkseven ${ }^{2}$, Suleyman Topal ${ }^{3}$ \\ ${ }^{1}$ Biology Department, Institute of Science, Dumlupinar University, Kütahya, Turkey \\ ${ }^{2}$ Plant Protection Department, Agricultural Faculty, Ege University, İzmir, Turkey \\ ${ }^{3}$ Biology Department, Faculty of Science and Letters, Dumlupinar University, Kütahya, Turkey \\ Email: duygusisek@hotmail.com, suleyman.turkseven@hotmail.com, topal_tr@yahoo.com
}

How to cite this paper: Sisek, D., Turkseven, S. and Topal, S. (2019) The Extract Obtained from Two Radish Cultivars (Raphanus sativus L. and Raphanus sativus L. var. radikula) Using Liquid Nitrogen Is Germination of Sterile Oats (Avena sterilis Subsp. sterilis) and Allelopathic Effect on Seedling Growth. Open Access Library Journal, 6: e5561. https://doi.org/10.4236/oalib.1105561

Received: June 25, 2019

Accepted: July 27, 2019

Published: July 30, 2019

Copyright $\odot 2019$ by author(s) and Open Access Library Inc.

This work is licensed under the Creative Commons Attribution International License (CC BY 4.0).

http://creativecommons.org/licenses/by/4.0/

(c) (7) Open Access

\begin{abstract}
The purpose of this study is to determine the allelopathic effects of extracts obtained by using liquid nitrogen from the plant of Antep radish (Raphanus sativus L.) and little radish (Raphanus sativus L. var. radikula) on germination and seedling growth of sterile oats. The experiments were carried out in six groups with root, stem and root + stem mixed extracts of radish plants (Antep and little radish). A novel method that we developed based on the principle of liquid nitrogen crushing was used for extraction. According to this method, Antep radish and little radish plant parts were frozen with liquid nitrogen aid and then crushed to powder. These powders obtained were stored at $-20^{\circ} \mathrm{C}$ for nine months until the experiments were established. The aqueous solutions prepared at specific concentrations $(0 \%, 1 \%, 2 \%, 4 \%, 8 \%$, $16 \%$ ) from the obtained radish powders were applied as $5 \mathrm{ml}$ to per each petri dishes contain 10 seeds on Whatman No: 1 double layer filter paper. Experiments were carried out in six replicates for each concentration. The prepared petri dishes were kept in the incubator at $15^{\circ} \mathrm{C}$ for 15 days. At the end of the experimental period, the number of germination of the seeds of sterile wild oat plant was evaluated by measuring the length of seedling root and stem. As a result, as the concentration of allelopathic solutions increased in all experimental groups, the number of germination and root and stem lengths of sterile wild oats decreased. Although allelopathic effects in all three experimental groups were observed in terms of germination number and seedling lengths,
\end{abstract}


the most significant effects were observed in the results of Antep radish root experiments. In this experiment group, the inhibition rate of root and stem length of weed seeds at a concentration of $16 \%$ were $86 \%$ and $82 \%$, respectively, when compared to the control. In addition, the germination number was reduced by $74.36 \%$ in the seeds at the highest concentration compared to the control. As a result of the study, it was determined that samples of radish plant crushed with liquid nitrogen were stored for a long time and showed high allelopathic effect on sterile wild oats plant.

\section{Subject Areas}

Agricultural Science

\section{Keywords}

Allelopathy, Avena sterilis, Antep Radish, Liquid Nitrogen

\section{Introduction}

Allelopathic compounds called allelochemicals are released from plant tissues into the environment in various ways (root exudation, leaf leaching, volatilisation and residue decomposition) [1] [2]. The use of allelopathy in agriculture has become increasingly important to reduce the negative effects of herbicides on the environment, human and food health and to eliminate the problem of herbicide-resistance in plants [3].

Many members of Brassicaceae family were investigated for allelopathic effects on germination and seedling growth of plants [4] [5] [6] [7].

The species belonging to Brassicaceae commonly contain glucosinolates, the secondary metabolite group containing-sulfur. The level of glucosinolates produced varies according to plant species, tissue type, stage of development and environmental conditions [8] [9]. Glucosinolates are degraded with the myrosinase enzyme to the isothiocyanates (ITC's) responsible for the allelopathic effect. In addition to ITC's, various hydrolysis products of glucosinolates (nitriles, thiocyanates and oxazolidinethiones and organic cyanides) also occur [10] [11].

Raphanus sativus and Raphanus sativus $\mathrm{L}$. var. radikula belong to Brassicaceae family are allelopathic cultivars that suppress the growth of weeds and a number of crops [12] [13] [14].

The purpose of this study is to determine the allelopathic effects of the extracts prepared by using liquid nitrogen from Antep radish (Raphanus sativus L.) and little radish (Raphanus sativus $\mathrm{L}$. var. radikula) on germination and seedling growth of sterile oats (Avena sterilis subsp. sterilis).

\section{Material \& Methods}

\subsection{Plant Material}

Antep and little radish were planted to be use as a donor plant in the Ege Un- 
iversty Plant Protection Research Fields, İzmir, located in $38^{\circ} 27^{\prime} 15.5340$ and $27^{\circ} 13^{\prime} 26.5008$. Two radish cultivars (Raphanus sativus and Raphanus sativus L. var. radikula) that matured at the end of the growing season were harvested in May 2017. In addition, the sterile oat used as a test plant was collected from the Ege University campus. Identification of the collected plants was made by using "Flora of Turkey and the East Aegean Islands" [15].

\subsection{Preparation of Aqueous Extracts and Experimental Design}

The radish plants were washed with tap water and cut into separated parts for preparing root, shoot, mixture (root $50 \%+$ shoot $50 \%$ ) extracts. Fresh tissues from each part were powdered aid of liquid nitrogen. The powder was diluted to give concentrations of $1,2,4,8$ and $16 \mathrm{~g} \cdot \mathrm{kg}^{-1}$ per $100 \mathrm{ml}$ of distilled water. Prepared solutions were homogenized in a magnetic stirrer for five minutes at 1200 rpm and distributed as $2 \mathrm{ml}$ to petri dishes containing 15 sterile oat seeds on two layers Whatman No: 1 filter paper. The seeds in control groups were moistened with distilled water. Experiments consisting of two groups, Antep radish and little radish, were conducted in a completely randomized design with four replications for each concentrate. The petri dishes kept in the incubator at $15^{\circ} \mathrm{C}$ for 10 days to observe germination and seedling development of sterile oat seeds. At the end of the period, germinated seeds were counted, root and shoot lengths of germinated seeds were measured. A seed with $0.5 \mathrm{~cm}$ of root was considered germinated. The inhibition percentage was calculated using the following equation:

Inhibition percentage $=[($ Control - Aqueous extract $) /$ Control $] \times 100$

\subsection{Statistical Analysis}

The data analysis was performed using one-way analysis of variance (ANOVA) in SPSS ver.16.0.Statistical differences $(p \leq 0.05)$ between treatments were determined using Duncan's multiple range test.

\section{Results and Discussion}

\subsection{Germination Percentage}

All extracts obtained from different parts of Antep radish and little radish pronouncedly inhibited the seed germination of sterile oats at the highest concentration (16\%). The degree of inhibition gradually increased with the concentration of Antep radish extracts. Among Antep Radish extracts, the most inhibitory effect was observed in root extracts, especially at $16 \%$ concentration with a reduction of $74.36 \%$ (Figure 1).

All extract applications of Antep radish were found to be more effective than little radish extracts on seed germination. Among the little radish extract applications at $16 \%$ concentration, it was determined that the most effective application was mixed extract $(37.73 \%)$, while the least effective one was the stem 


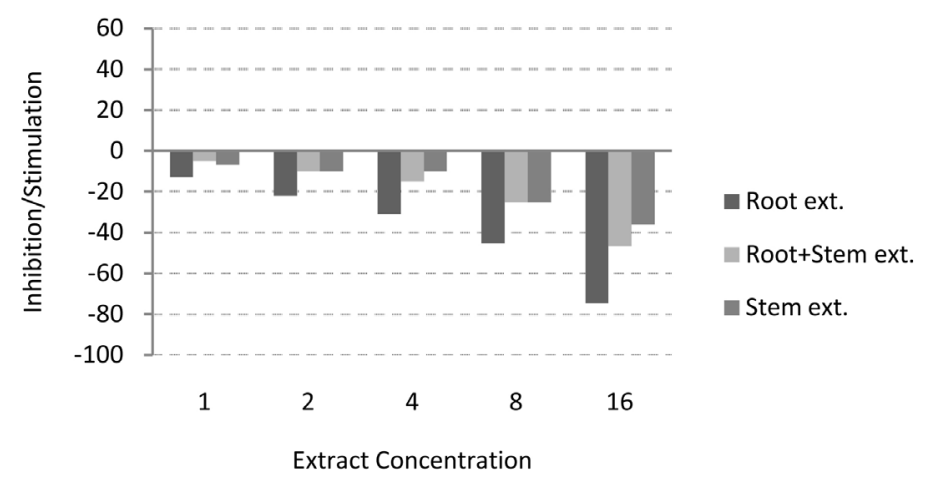

Figure 1. Effects (\%) of extracts from different parts (root, stem and root + stem extracts) of Antep radish on germination of sterile oat seeds.

extract application (26.32\%). However, low concentrations of the little radish stem $(1 \%)$ and mixture extracts $(1 \%-2 \%)$ stimulated the germination of sterile oats (Figure 2).

Both Antep radish and little radish applications showed statistically significant differences between concentrations $(\mathrm{p}<0.05)$ (Table 1$)$.

\subsection{Shoot Elongation}

The effects of extracts obtained from different parts of antep radish and little radish on shoot elongation of sterile oat are shown in Figure 3 and Figure 4. All the extracts of Antep radish significantly reduced the shoot elongation at concentrations of $8 \%$ and $16 \%(\mathrm{p}<0.05)$ (Table 2).

Several studies have shown that extracts from different tissues of various allelopathic plants suppress the growth of test plants at different rates [16]. These findings were supported by the results of this study. It was observed that the root extract of Antep radish, which has the most significant effect, decreased the shoot elongation of the seeds at $16 \%$ concentration by $82.84 \%$. However, the stem extract at the same concentration reduced the shoot elongation by $52.14 \%$. It has been shown in previous studies that aqueous allelopathic solutions at low concentration may have a stimulatory effect. Similarly in this study, Antep radish stem extract at low concentrations ( $1 \%$ and $4 \%)$ stimulated the shoot elongation. The degree of inhibition gradually increased with the concentration of Antep radish extracts (Figure 3 ).

The effects of little radish extracts on shoot elongation varied at different concentrations. At $16 \%$ concentration, stem extract of little radish showed the most effective result (70.84\%) on shoot elongation, while root extracts showed the lowest effect $(30.26 \%)$. At $1 \%$ and $2 \%$ concentrations, mixture and stem extracts of little radish showed the stimulatory effect on shoot elongation (Figure 4).

The effect of the extracts of different parts of the Antep radish on the shoot elongation was in the following order: root $>$ mixture $>$ stem. However, the effect of little radish extracts is opposite; stem $>$ mixture $>$ root. 


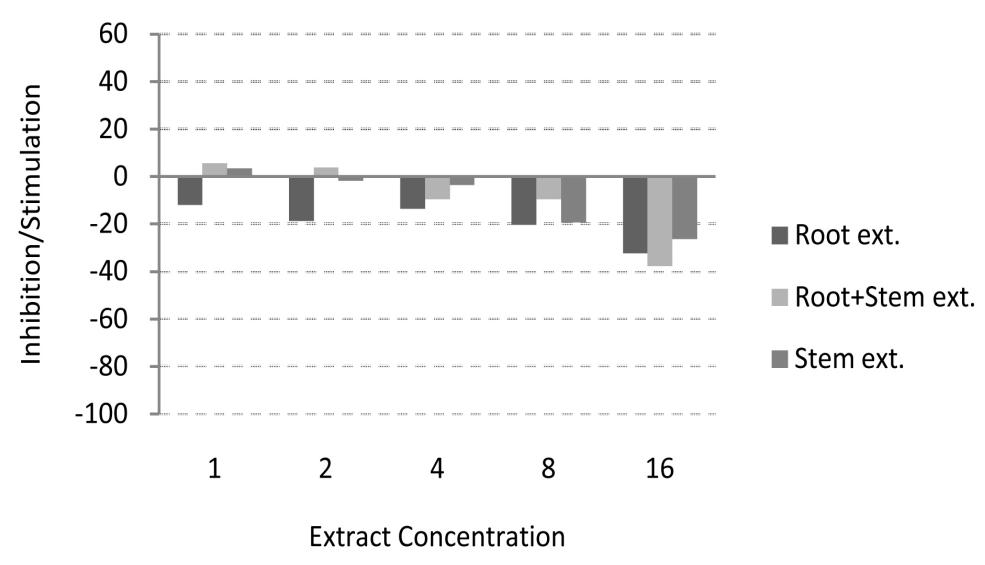

Figure 2. Effects of extracts (\%) from different parts (root, stem and root + stem extracts) of little radish on germination of sterile oat seeds.

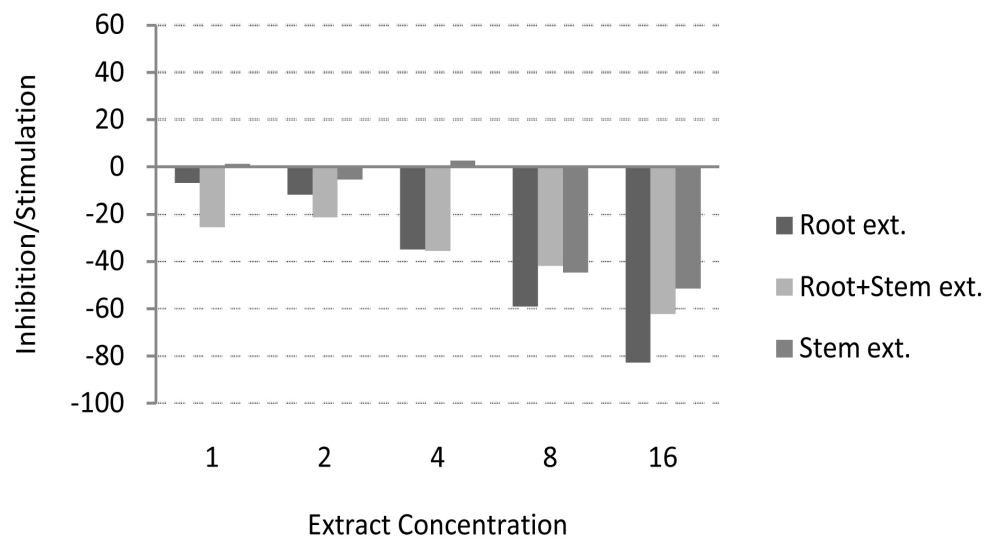

Figure 3. Effects (\%) of extracts from different parts (root, stem and root + stem extracts) of Antep radish on shoot elongation of sterile oat seeds.

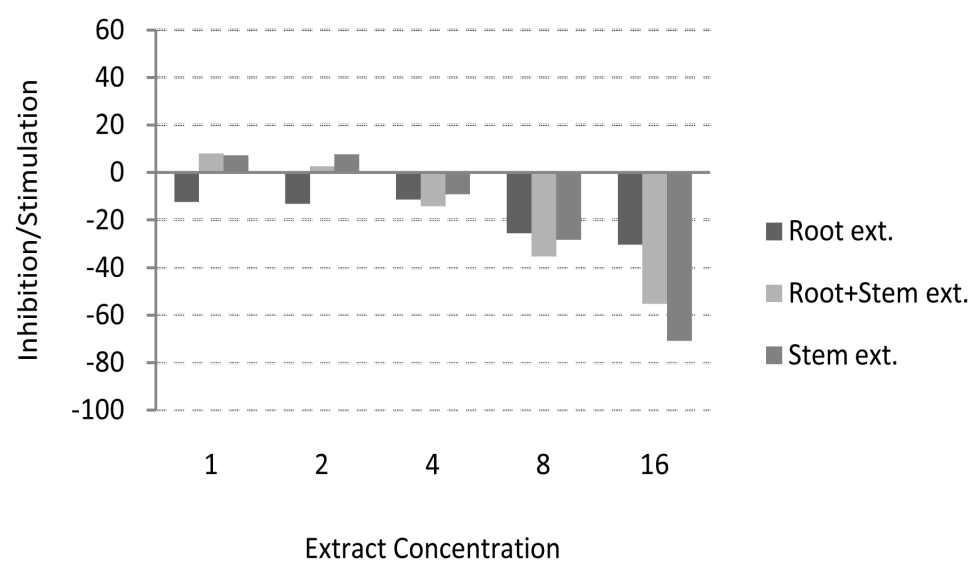

Figure 4. Effects (\%) of extracts from different parts (root, stem and root + stem extracts) of little radish on shoot elongation of sterile oat seeds.

\subsection{Root Elongation}

Both cultivars of radish significantly $(\mathrm{p}<0.05)$ reduced the root elongation of sterile oat, especially at $16 \%$ concentration (Table 3 ). 
Table 1. Allelopathic effect of extracts of Antep radish and little radish on germination of sterile oat seeds.

\begin{tabular}{|c|c|c|c|c|c|c|}
\hline \multicolumn{7}{|c|}{ Germination Rate $(\%) \pm \mathrm{SE}^{*}$} \\
\hline \multirow{2}{*}{$\begin{array}{l}\text { Ext. } \\
\text { Conc. } \\
(\%)\end{array}$} & \multicolumn{3}{|c|}{ Antep radish } & \multicolumn{3}{|c|}{ Little radish } \\
\hline & Root ext. & Stem ext. & $\begin{array}{l}\text { Root }+ \text { Stem } \\
\quad \text { ext. }\end{array}$ & Root ext. & Stem ext. & $\begin{array}{c}\text { Root }+ \text { Stem } \\
\text { ext. }\end{array}$ \\
\hline 0 & $91^{\mathrm{d}} \pm 3.07$ & $100^{\mathrm{c}} \pm 0$ & $100^{c} \pm 0$ & $98.33^{\mathrm{b}} \pm 1.67$ & $95.00^{\mathrm{b}} \pm 3.41$ & $88.33^{\mathrm{b}} \pm 4.77$ \\
\hline 1 & $80^{\mathrm{cd}} \pm 5.77$ & $93.33^{c} \pm 3.33$ & $95^{\mathrm{c}} \pm 3.42$ & $86.67^{\mathrm{ab}} \pm 4.21$ & $98.33^{\mathrm{b}} \pm 1.67$ & $93.33^{\mathrm{b}} \pm 2.11$ \\
\hline 2 & $71.67^{\mathrm{bc}} \pm 4.77$ & $93.33^{c} \pm 3.33$ & $90^{b c} \pm 6.32$ & $80^{\mathrm{ab}} \pm 5.77$ & $93.33^{\mathrm{ab}} \pm 3.33$ & $91.67^{\mathrm{b}} \pm 4.77$ \\
\hline 4 & $63.33^{\mathrm{bc}} \pm 12.82$ & $90^{\mathrm{bc}} \pm 5.16$ & $85^{\mathrm{bc}} \pm 6.71$ & $85^{\mathrm{ab}} \pm 6.19$ & $78.33^{\mathrm{ab}} \pm 13.76$ & $80^{\mathrm{b}} \pm 6.83$ \\
\hline 8 & $50^{\mathrm{b}} \pm 11.83$ & $75^{\mathrm{ab}} \pm 4.28$ & $75^{\mathrm{b}} \pm 5.63$ & $78.33^{\mathrm{ab}} \pm 5.43$ & $76.67^{\mathrm{ab}} \pm 9.88$ & $80^{\mathrm{b}} \pm 8.16$ \\
\hline 16 & $23.33^{\mathrm{a}} \pm 10.22$ & $63.33^{\mathrm{a}} \pm 10.54$ & $53.33^{\mathrm{a}} \pm 9.55$ & $66.67^{\mathrm{a}} \pm 11.16$ & $70.00^{\mathrm{a}} \pm 6.83$ & $55^{\mathrm{a}} \pm 8.47$ \\
\hline
\end{tabular}

${ }^{*}$ Means followed by different letters in the same column are significantly different from each other at $5 \%$ probability according to Duncan Test (SE: Standard Error).

Table 2. Allelopathic effect of extracts of Antep radish and little radish on shoot elongation of sterile oat.

\begin{tabular}{ccccccc}
\hline \multicolumn{6}{c}{ Shoot elongation $(\mathrm{cm}) \pm \mathrm{SE}^{*}$} \\
$\begin{array}{c}\text { Ext. } \\
\begin{array}{c}\text { Conc. } \\
(\%)\end{array}\end{array}$ & Root ext. & Stem ext. & $\begin{array}{c}\text { Root }+ \text { Stem } \\
\text { ext. }\end{array}$ & Root ext. & Stem ext. & $\begin{array}{c}\text { Root }+ \text { Stem } \\
\text { ext. }\end{array}$ \\
\hline 0 & $10.72^{\mathrm{d}} \pm 0.74$ & $15.13^{\mathrm{b}} \pm 1.46$ & $15.81^{\mathrm{c}} \pm 0.99$ & $15.53^{\mathrm{b}} \pm 0.84$ & $13.79^{\mathrm{c}} \pm 0.75$ & $12.35^{\mathrm{c}} \pm 0.76$ \\
1 & $10.01^{\mathrm{cd}} \pm 0.70$ & $15.32^{\mathrm{b}} \pm 1.54$ & $11.78^{\mathrm{b}} \pm 1.18$ & $13.62^{\mathrm{ab}} \pm 0.81$ & $14.79^{\mathrm{c}} \pm 0.79$ & $13.34^{\mathrm{c}} \pm 0.70$ \\
2 & $9.46^{\mathrm{cd}} \pm 1.11$ & $14.32^{\mathrm{b}} \pm 0.65$ & $12.45^{\mathrm{b}} \pm 1.33$ & $13.49^{\mathrm{ab}} \pm 1.09$ & $14.84^{\mathrm{c}} \pm 0.48$ & $12.67^{\mathrm{c}} \pm 0.70$ \\
4 & $6.98^{\mathrm{bc}} \pm 1.38$ & $15.54^{\mathrm{b}} \pm 1.92$ & $10.19^{\mathrm{b}} \pm 1.05$ & $13.78^{\mathrm{ab}} \pm 0.86$ & $12.53^{\mathrm{c}} \pm 0.54$ & $10.60^{\mathrm{bc}} \pm 1.09$ \\
8 & $4.40^{\mathrm{ab}} \pm 1.34$ & $8.38^{\mathrm{a}} \pm 0.91$ & $9.19^{\mathrm{b}} \pm 0.81$ & $11.56^{\mathrm{a}} \pm 1.14$ & $9.88^{\mathrm{b}} \pm 1.25$ & $8.00^{\mathrm{ab}} \pm 1.55$ \\
16 & $1.84^{\mathrm{a}} \pm 0.99$ & $7.24^{\mathrm{a}} \pm 1.57$ & $5.96^{\mathrm{a}} \pm 1.14$ & $10.83^{\mathrm{a}} \pm 1.57$ & $4.02^{\mathrm{a}} \pm 0.80$ & $5.52^{\mathrm{a}} \pm 0.80$ \\
\hline
\end{tabular}

${ }^{*}$ Means followed by different letters in the same column are significantly different from each other at $5 \%$ probability according to Duncan Test (SE: Standard Error).

Table 3. Allelopathic effect of extracts of Antep radish and little radish on root elongation of sterile oat.

\begin{tabular}{ccccccc}
\hline \multicolumn{5}{c}{ Root elongation $(\mathrm{cm}) \pm \mathrm{SE}^{*}$} \\
\hline $\begin{array}{c}\text { Ext. } \\
\begin{array}{c}\text { Conc. } \\
(\%)\end{array}\end{array}$ & Root ext. & Stem ext. & $\begin{array}{c}\text { Root }+ \text { Stem } \\
\text { ext. }\end{array}$ & Root ext. & Stem ext. & $\begin{array}{c}\text { Root }+ \text { Stem } \\
\text { ext. }\end{array}$ \\
\cline { 2 - 7 } & $10.57^{\mathrm{d}} \pm 0.39$ & $13.80^{\mathrm{b}} \pm 1.38$ & $15.58^{\mathrm{d}} \pm 0.92$ & $12.11^{\mathrm{c}} \pm 0.63$ & $9.38^{\mathrm{c}} \pm 0.48$ & $10.16^{\mathrm{c}} \pm 0.41$ \\
\hline 0 & $8.82^{\mathrm{d}} \pm 0.88$ & $13.86^{\mathrm{b}} \pm 1.45$ & $11.52^{\mathrm{c}} \pm 1.00$ & $8.09^{\mathrm{b}} \pm 0.51$ & $9.30^{\mathrm{c}} \pm 0.23$ & $8.64^{\mathrm{c}} \pm 0.77$ \\
1 & $7.92^{\mathrm{cd}} \pm 0.67$ & $13.26^{\mathrm{b}} \pm 0.63$ & $11.17^{\mathrm{c}} \pm 1.25$ & $8.5^{\mathrm{b}} \pm 0.61$ & $8.75^{\mathrm{c}} \pm 0.64$ & $9.85^{\mathrm{c}} \pm 0.81$ \\
2 & $5.82^{\mathrm{bc}} \pm 1.28$ & $12.22^{\mathrm{b}} \pm 1.12$ & $9.35^{\mathrm{bc}} \pm 1.17$ & $8.61^{\mathrm{b}} \pm 1.43$ & $9.96^{\mathrm{c}} \pm 0.38$ & $6.65^{\mathrm{b}} \pm 0.48$ \\
4 & $3.87^{\mathrm{ab}} \pm 1.02$ & $7.77^{\mathrm{a}} \pm 0.76$ & $6.85^{\mathrm{ab}} \pm 0.72$ & $7.97^{\mathrm{b}} \pm 0.81$ & $6.14^{\mathrm{b}} \pm 0.83$ & $6.24^{\mathrm{b}} \pm 1.02$ \\
16 & $1.44^{\mathrm{a}} \pm 0.81$ & $6.06^{\mathrm{a}} \pm 1.18$ & $4.51^{\mathrm{a}} \pm 0.81$ & $5.28^{\mathrm{a}} \pm 0.76$ & $2.98^{\mathrm{a}} \pm 0.44$ & $3.11^{\mathrm{a}} \pm 0.36$ \\
\hline
\end{tabular}

${ }^{*}$ Means followed by different letters in the same column are significantly different from each other at $5 \%$ probability according to Duncan Test (SE: Standard Error). 
Root extract of Antep radish prominently reduced root elongation of sterile oat at all concentrations except $1 \%$ and $2 \%$. High inhibitory effects were exhibited particularly in $8 \%$ and $16 \%$ concentration by $63.38 \%$ and $86.37 \%$ respectively (Figure 5).

Root elongation of sterile was affected approximately similar rates by all littler a dish extracts prepared at $8 \%$ concentration. At the highest concentration, the root extract was found to suppress the root elongation (56.40\%) at a lesser rate than the stem (68.23\%) and mixed extracts (69.39\%) (Figure 6).

These results are supported by the finding of Uremis et al. (2009), who reported that extracts of Antep radish and little radish had an inhibitory effect on the germination and seedling length of sterile oat [17]. However, when the findings are compared, it is clear that the extraction method used in our study gives more effective results than the other methods and the plant parts exhibit different allelopathic effects.

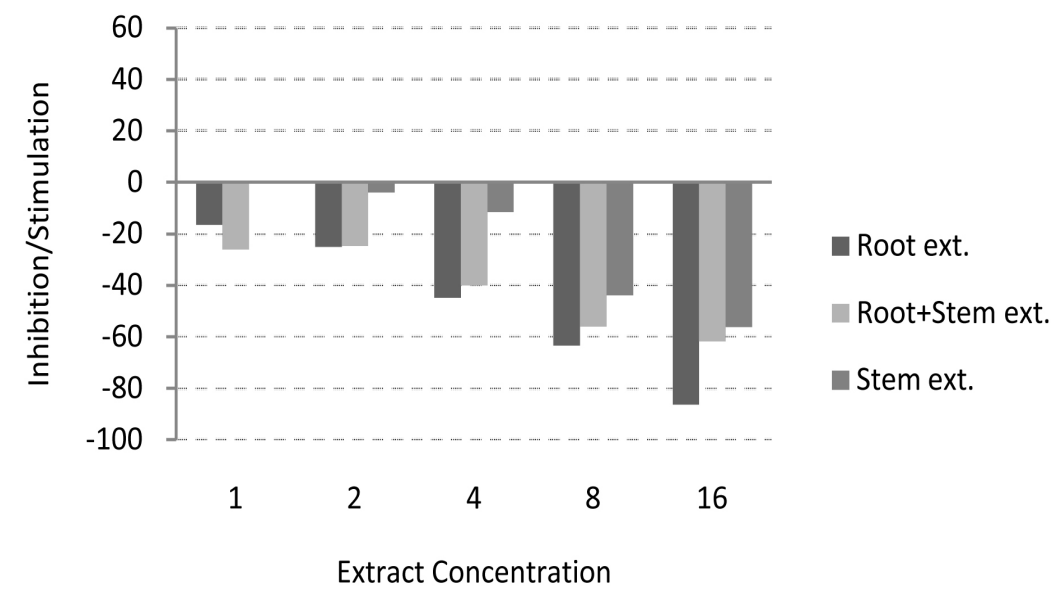

Figure 5. Effects (\%) of extracts from different parts (root, stem and root + stem extracts) of Antep radish on root elongation of sterile oat seeds.

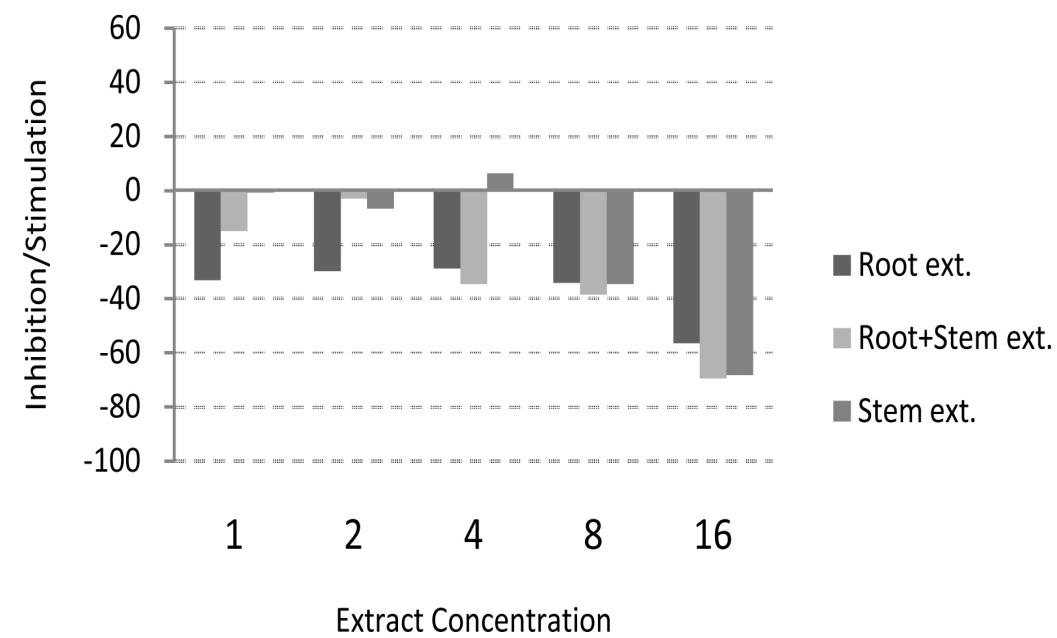

Figure 6. Effects (\%) of extracts from different parts (root, stem and root + stem extracts) of little radish on root elongation of sterile oat seeds. 


\section{Conclusion}

In the study, it has shown that aqueous extracts prepared from radish cultivars have inhibitory effects on seed germination and seedling growth of wild oats. It has also emphasized that the use of liquid nitrogen as an extraction method can give effective results. We recommend that this study shed light on future studies for the production of natural herbicides from allelopathic plants and the results obtained from this study should be supported with field studies.

\section{Conflicts of Interest}

The authors declare no conflicts of interest regarding the publication of this paper.

\section{References}

[1] Latif, S., Chiapusio, G. and Weston, L.A. (2017) Allelopathy and the Role of Allelochemicals in Plant Defence. In: Advances in Botanical Research, Vol. 82, Academic Press, Cambridge, 19-54. https://doi.org/10.1016/bs.abr.2016.12.001

[2] Inderjit (2001) Soil: Environmental Effects on Allelochemical Activity. Agronomy Journal, 93, 79-84.

[3] Xuan, T.D., Tsuzuki, E., Tawata, S. and Khanh, T.D. (2004) Methods to Determine Allelopathic Potential of Crop Plants for Weed Control. Allelopathy Journal, 13, 149-164.

[4] Uremis, I., Arslan, M. and Uludag, A. (2005) Allelopathic Effects of Some Brassica Species on Germination and Growth of Cutleaf Ground-Cherry (Physlis angulata L.). Journal of Biological Sciences, 5, 661-665. https://doi.org/10.3923/jbs.2005.661.665

[5] Turk, M.A. and Tawaha, A.M. (2002) Inhibitory Effects of Aqueous Extracts of Black Mustard on Germination and Growth of Lentil. Journal of Agronomy, 1, 28-30. https://doi.org/10.3923/ja.2002.28.30

[6] Turk, M.A. and Tawaha, A.M. (2003) Allelopathic Effect of Black Mustard (Brassica nigra L.) on Germination and Growth of Wild Oat (Avena fatua L.). Crop Protection, 22, 673-677. https://doi.org/10.1016/S0261-2194(02)00241-7

[7] Haramoto, E.R. and Gallandt, E.R. (2005) Brassica Cover Cropping: I. Effects on Weed and Crop Establishment. Weed Science, 53, 695-701.

https://doi.org/10.1614/WS-04-162R.1

[8] Fahey, J.W., Zalemann, A.T. and Talalay, P. (2001) The Chemical Diversity and Distribution of Glucosinolates and Isothiocyanates among Plants. Phytochemistry, 56, 5-51. https://doi.org/10.1016/S0031-9422(00)00316-2

[9] Bohinc, T., Goreta Ban, S., Ban, D. and Trdan, S. (2012) Glucosinolates in Plant Protection Strategies. Archives of Biological Sciences, 64, 821-828.

https://doi.org/10.2298/ABS1203821B

[10] Petersen, J., Belz, R., Walker, F. and Hurle, K. (2001) Weed Suppression by Release of Isothiocyanates from Turniprape Mulch. Agronomy Journal, 93, 37-43. https://doi.org/10.2134/agronj2001.93137x

[11] Bones, A.M. and Rossiter, J.T. (1996) The Myrosinase-Glucosinolate System, Its Organisation and Biochemistry. Physiologia Plantarum, 97, 194-208.

https://doi.org/10.1111/j.1399-3054.1996.tb00497.x 
[12] Arslan, M., Uremis, I. and Uludag, A. (2005) Determining Bio-Herbicidal Potential Rapeseed, Radish and Turnip Extracts on Germination Inhibition of Cutleaf Ground-Cherry (Physalis angulata L.) Seeds. Agronomy Journal, 4, 134-137. https://doi.org/10.3923/ja.2005.134.137

[13] Uremis, I., Ahmet, M., Uludag, A. and Sangun, M. (2009) Allelopathic Potential of Residue of 6 Brassica Species on Johnsongrass [Sorghum haplense (L.) Pers.]. African Journal of Biotechnology, 8, 3497-3501.

[14] De Moraes Gomes, M., Bertoncelli, D.J., Alves, G.A.C., Freiria, G.H., Furlan, F.F., Gomes, G.R., Favoretto, V.R., Neto, H.F.I., Omura, M.S. and De Souza, J.R.P. (2017) Allelopathic Potential of the Aqueous Extract of Raphanus sativus L. on the Germination of Beans and Corn Seeds. Open Access Library Journal, 4, 1.

https://doi.org/10.4236/oalib.1103590

[15] Davis, P.H. (1965) Flora of Turkey.

[16] Sodaeizadeh, H., Rafieiolhossaini, M., Havlik, J. and Van Damme, P. (2009) Allelopathic Activity of Different Plant Parts of Peganum harmala L. and Identification of Their Growth Inhibitors Substances. Plant Growth Regulation, 59, 227-236. https://doi.org/10.1007/s10725-009-9408-6

[17] Uremis, I., Arslan, M. and Uludag, A. (2009) Investigations of Allelopathic Effects of Some Radish and Turnip Extracts on Weeds. III. Plant Protection Congress, Van, 15-18 July 2009, 279 p. 